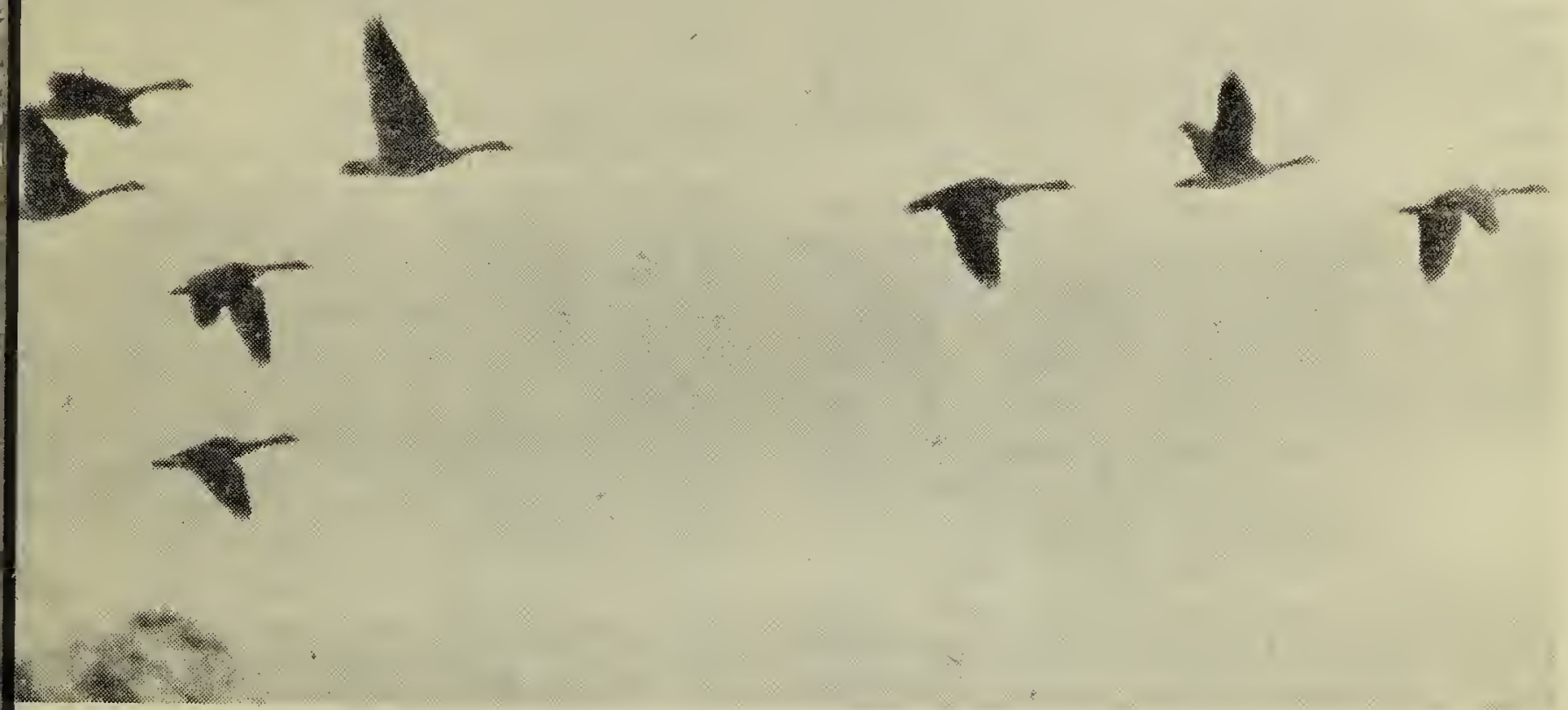

WASCANA CANADA GEESE

Photo by F. W. Lahrman

\title{
Transformation
}

Five Canada geese flew over my head In stately line with wings outspread, And the hills twined green before my eyes, The icy river flowed summerwise, Forgotten winter's frost and snow, Springtime entered my heart, aglow, When five Canada geese flew over my head In stately line with wings outspread.

printed from the Saskatchewan Poetry Book

-Clarissa Stewart

\section{The Horned Lark's Arrival}

\section{By RONALD HOOPER, Somme, Sask.}

Just as the mid-July arrival of the Solitary Sandpiper is the forener of autumn, and the mid-October arrival of the Snow Bunting is a elude to winter, when the Horned Larks are running over the snow ifts and singing merrily from the fence posts, we know that spring is st around the corner. When we have spent all winter without hearing $\epsilon$ song of a bird, the simply sung ditty of the Horned Lark makes an cellent substitute for the clear notes of an Oriole, or the squeaky ejacuticns of a Catbird. It is always a pleasure to have our feathered friends me home for the summer, with the marvellous timing described in the ords of the Bible: "Yea, the stcrk in the heaven knoweth her appointed mes; and the turtle and the crane and the swallow observe the time of eir coming." 